\title{
JOURNAL.RU
}

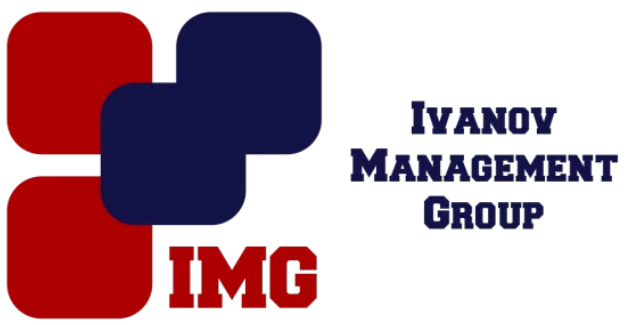

Стороженко И.И., Омельченко А.В., Петряев А.С., Николаева К.В. Военно-медичинская академия им.С.М. Кирова Санкт-Петербург, Россия

doi: 10.18411/lj-25-12-2016-2-10

idsp 000001:lj-25-12-2016-2-10

\section{Средства и методы повышения работоспособности у военнослужащих медицинского профиля}

\section{Аннотация}

В системе мероприятий по созданию комфортных условий труда у военнослужащих медицинского профиля большое значение имеют рациональные режимы воинского труда и отдыха, обеспечивающие высокую эффективность их работоспособности и сохранение крепкого здоровья, т.е. достижения такого состояния организма человека, когда функции всех его органов и систем уравновешены с внешней средой и отсутствуют болезненные изменения.

Ключевые слова: умственная и физическая работоспособность; критерии здоровья; физическая, нервно-психическая и эмоциональная нагрузка; профессиональное здоровье, долголетие; физическая подготовленность.

\section{Abstract}

In the system of measures for creation of comfortable conditions of labour from the military medical profile of great value and have a rational military regimes of work and rest, providing high efficiency of their health and maintaining good health, i.e., to achieve this state of human body when the functions of all its organs and systems are balanced with the external environment and there are no painful changes.

Keywords: mental and physical performance; criteria of health; physical, mental and emotional stress; occupational health, longevity; physical fitness.

Сегодня человеку продолжает казаться, что здоровье будет всегда, т. к. забота о ней переложена на плечи государства, медицинской отрасли. Человек стал потребителем, а не производителем своего здоровья. Выбранный образ и стиль жизни курсантов и слушателей академии в период обучения корреляционно связан с умственной и физической работоспособностью. 
В определении требований, предъявляемых спецификой военнопрофессиональной деятельности военнослужащих медицинского профиля к уровню развития его умственной и физической работоспособности и физической подготовленности, а также необходимостью разработки и обосновании новых методик развития и повышения их уровня, и обусловлена актуальность нашего исследования.

Цель исследования заключается в том, чтобы провести всесторонний анализ военно-профессиональной деятельности специалистов медицинского профиля, выявить основные профессионально важные качества (ПВК), а также обосновать и разработать комплекс повышения работоспособности.

В ходе исследования проведен широкий анализ литературы, позволяющий оценить военно-профессиональную деятельность специалистов медицинского профиля, использованы средства и методы физической подготовки для поддержания высокого уровня работоспособности и физической подготовленности.

На данном этапе работы обоснован, разработан и экспериментально проверен специальный комплекс повышения работоспособности у курсантов академии с использованием средств и методов физической подготовки.

На основе полученных результатов установлено, что в системе мероприятий по созданию комфортных условий труда у военнослужащих медицинского профиля большое значение имеют рациональные режимы воинского труда и отдыха, обеспечивающие высокую эффективность функционирования умственной и физической работоспособности, которые являются одним из главных показателей степени здоровья.

На протяжении многих лет специалистами академии проводятся исследования по определению профессионально важных качеств военного врача, которые подразделяют на профессиональные, психологические и психофизиологические. В частности, в структуре определенных экспертами характеристик определяются:

- волевые качества (самообладание, выдержка, решительность, целеустремленность, дисциплинированность);

- организаторские способности;

- качества личности (трудолюбие, высокий уровень ответственности, умение взять на себя ответственность за принятие решений, самостоятельность, честность, обязательность, принципиальность.

В комплекс ПВК вошли и качества, отражающие сохранение работоспособности в условиях аварийной ситуации и дефицита времени и выносливость к длительной и напряженной умственной деятельности.

Труд военнослужащего медицинского профиля - особый вид труда в его деятельности. На его умственную и физическую работоспособность влияет большое количество факторов: состояние здоровья, уровень тренированности, опыт, физическое и психическое состояние, мотивация и организация труда; окружающая среда; оперативная и долговременная память, концентрация 
внимания, эмоционально-волевые качества, нервно-психическая устойчивость, гипокинезия, гиподинамия и др.

В процессе систематических тренировок физической подготовкой и спортом происходит постепенная адаптация к физическим нагрузкам.

Одной из важнейших задач тренировок явилось повышение работоспособности, для чего нами использованы варианты тренировки специального комплекса физических упражнений в процессе обучения: из НФП - 2009; утренняя физическая зарядка; действия, выполняемые в процессе повседневной деятельности и комплексный психофизиологический тест.

На данном этапе исследования установлено, что создание комфортных условий труда военнослужащим медицинского профиля большое значение имеют рациональные режимы воинского труда и отдыха при рациональном применении различных средств и методов физической подготовки.

Наиболее важным физическим качеством для здоровья военнослужащих медицинского профиля является общая выносливость и один из ее главных критериев - высокий уровень умственной и физической работоспособности.

Обобщенными характеристиками внедрения в учебный процесс комплекса физических упражнений явилось обеспечение у курсантов состояния высокого уровня работоспособности, физической подготовленности, нервно-психической и эмоционально-волевой устойчивости к сбивающим факторам.

Специальный комплекс физических упражнений не требует дополнительной материальной базы по физической подготовке, что повышает и экономический эффект процесса обучения курсантов академии.

\section{Литература}

1. Источник №1. Григорович Е.С. Производственная гимнастика для работников основных групп умственного труда: Метод. рекомендации / Малуха И.Н., Григорович Е.С., Трофименко А.М., Мн.: МГМИ, 2000. - 39 c.

2. Источник №2. Макаров Р.Н. Научно-педагогические основы организации психофизической подготовки летного состава / Р.Н. Макаров. - М.: ВВА им. Ю.А. Гагарина, 1980. - 107 с.

3. Источник №3. Марищук В.Л. О корригировании и совершенствовании некоторых физических и психических профессионально важных качеств / В.Л. Марищук // Психолого-педагогические аспекты физической подготовки. - Л.: ВДКИФК, 1985. - с. 5-10.

4. Источник №4. Марищук В.Л. Принципы и методы обучения в военной педагогике и физической подготовке. - Л.: ВДКИФК, 1988.- 60 с.

5. Источник №5. Марищук В.Л. О преодолении излишнего эмоционального возбуждения средствами физической подготовки / В.Л. Марищук // Труды факультета. Вып. ХХХ. - Л.: КВИФК, 1962. - 25 с. 